\title{
Characterization of the AZ31/AW-6060 Joint Fabricated using Compound Casting with a Zn Interlayer at Relatively Low Temperature Conditions
}

\author{
Tomasz Bucki1,* - Marek Konieczny ${ }^{1}$ - Dana Bolibruchova ${ }^{2}$ - Sylwia Rzepa ${ }^{3}$ \\ ${ }^{1}$ Kielce University of Technology, Faculty of Mechatronics and Mechanical Engineering, Poland \\ 2University of Zilina, Faculty of Mechanical Engineering, Slovak Republic \\ ${ }^{3}$ COMTES FHT a.s., Mechanical Testing and Thermophysical Measurement Department, Czech Republic
}

The work deals with the fabrication of a joint between AZ31 magnesium alloy and AW-6060 aluminium alloy with the use of a Zn interlayer. The Zn layer was produced on the surface of an AW-6060 alloy insert by diffusion bonding. The insert was then placed inside a steel mould and kept at room temperature. The joint was produced using compound casting by filling the mould with liquid AZ31 alloy, heated to $650{ }^{\circ} \mathrm{C}$. The microstructure of the bonding zone formed between joined alloys was analysed using an optical microscope and a scanning electron microscope equipped with an energy dispersive X-ray spectroscope. The properties of the joint were examined using Vickers microhardness measurements and simple shear strength testing. As a result of the experiment, the $400 \mu \mathrm{m}$ thick bonding zone with a complex microstructure was formed between the alloys. The microstructural analysis showed that the bonding zone reveals a high concentration of $\mathrm{Zn}$ and $\mathrm{Mg}$. The layers of a eutectoid (a MgZn phase + a solid solution of $\mathrm{Al}$ and $\mathrm{Zn}$ in $\mathrm{Mg}$ ), a $\mathrm{Mg}_{5} \mathrm{Al}_{2} \mathrm{Zn}_{2}$ phase and a $\mathrm{Mg}(\mathrm{Al}, \mathrm{Zn})_{2}$ phase with fine particles of other phases were observed there. The bonding zone was characterized by relatively high microhardness, which was related to the brittleness of the constituents. The shear strength of the examined joint was $19.6 \pm 2.5 \mathrm{MPa}$.

Keywords: compound casting, magnesium alloy, aluminium alloy, zinc interlayer, microstructure, mechanical properties

\section{Highlights}

- The AZ31/AW-6060 joint was fabricated by compound casting with the use of a Zn interlayer.

- $\quad$ The Zn layer was produced on the surface of the AW-6060 alloy insert to act as an interlayer.

- The compound casting involved pouring the liquid AZ31 magnesium alloy at $650{ }^{\circ} \mathrm{C}$ onto a solid AW-6060 aluminium alloy insert placed in a steel mould and kept at room temperature.

- The study focused on the analysis of the microstructure and examinations of microhardness and shear strength of the fabricated joint.

\section{INTRODUCTION}

In recent years, there has been a noticeable increase in the application of bimetallic elements based on various metals and their alloys. Such products have unique properties that cannot be achieved with a single alloy. A promising solution is the production of bimetals based on light alloys: magnesium and aluminium. The combination of these materials into one element allows taking the advantages of both alloys: the low density of the magnesium alloy and good resistance to corrosion and abrasion of the aluminium alloy [1] and [2]. The literature review shows that the following methods are used to join magnesium alloys with aluminium alloys: diffusion bonding [3], ultrasonic welding [4], resistance spot welding [5], friction stir welding [6]; explosive welding [7], tungsten inert gas (TIG), metal inert gas (MIG) and laser welding techniques [8] to [10], and compound casting [11].

The advantages of compound casting over other joining techniques include the possibility of producing joints with complex shapes, high efficiency, and a relatively simple and economical production process. The joining of magnesium to aluminium alloys by compound casting seems to be a promising direction that may contribute to the increase in the use of light alloys in various industries, mainly in the automotive industry. This technique involves pouring a liquid alloy onto a product made of a different material. The literature data [11] shows that joints with favourable properties can be fabricated by pouring liquid magnesium onto a solid aluminium insert placed in a casting mould. The typical bonding zone has a complex structure composed of continuous layers of $\mathrm{Al}_{3} \mathrm{Mg}_{2}(\beta)$ and $\mathrm{Mg}_{17} \mathrm{Al}_{12}(\gamma)$ intermetallic phases, as well as a layer of a eutectic $\left(\mathrm{a}_{17} \mathrm{Al}_{12}\right.$ phase + a solid solution of $\mathrm{Al}$ in $\mathrm{Mg}$ ). $\mathrm{Mg}$ - $\mathrm{Al}$ intermetallic phases are characterized by high brittleness, related to the low strength of the joint and the brittle nature of the fracture. The thickness of the bonding zone depends on the parameters of the casting process, such as the temperature of molten magnesium and temperature of the mould with an aluminium insert [12], Mg-to-Al volume ratio [13] and [14], method of casting [15], and 
pressure in the mould [16]. The research results on the properties of such joints show that favourable strength is achieved for the joints with a thin bonding zone. Some studies have focused on the fabrication of joints between $\mathrm{Mg}$ and $\mathrm{Al}$ alloys, e.g., AZ91/A356 [17] and [18], AZ91/AlSi17 [19] and [20], AZ91/AlSi12 [21], ZE41/AlSi12 [22], AZ31/AW-6060 [23]. The results of the above-mentioned works indicate that the presence of alloying elements may lead to significant modification of the structure of the created bonding zone and can affect the mechanical properties of the joint. The properties of the joint can also be improved by using interlayers. Such modification is meant to reduce or block the possibility of the formation of $\mathrm{Mg}$ $\mathrm{Al}$ intermetallic phases and replace them with other phases with better properties. Recent studies showed that good results can be achieved when the $\mathrm{Zn}$ [23], Ni [24] or $\mathrm{Ni}+\mathrm{Cu}$ [25] interlayers are used.

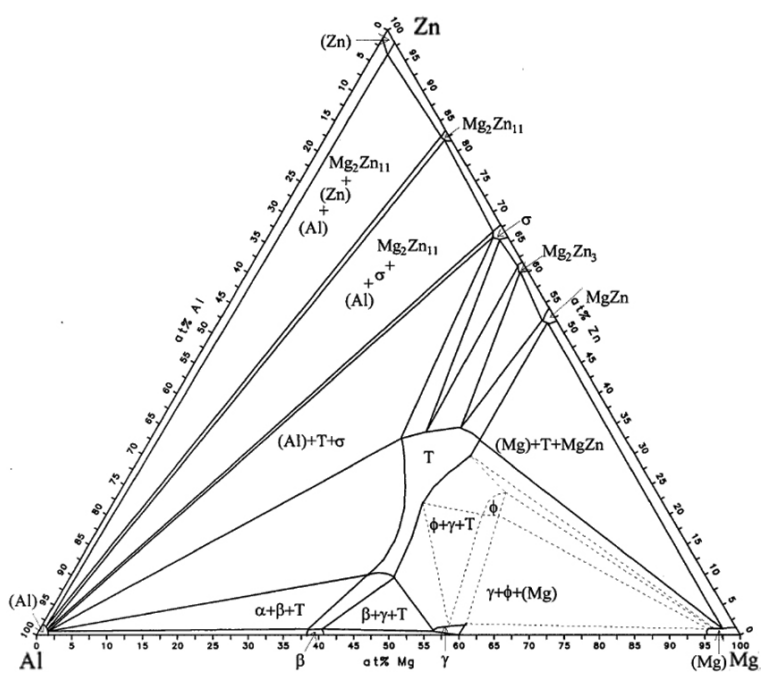

Fig. 1. Isothermal cross-section of the Mg-Al-Zn phase diagram at the temperature of $25^{\circ} \mathrm{C}$ [29] (C) MMMS and ASM Int.

In order to understand the processes of formation of the $\mathrm{Mg}$ alloy/Al alloy joint with the use of a $\mathrm{Zn}$ interlayer, it is necessary to become acquainted with the Mg-Al [26], Mg-Zn [27] and Al-Zn [28] phase diagrams as well as the $\mathrm{Mg}-\mathrm{Al}-\mathrm{Zn}$ ternary diagram [29]. Fig. 1 shows the isothermal cross-section of the $\mathrm{Mg}-\mathrm{Al}-\mathrm{Zn}$ phase diagram at the temperature of $25{ }^{\circ} \mathrm{C}$. The system, beyond the binary phases, also includes two ternary phases, marked as $\varphi$ (also known as $\mathrm{Mg}_{5} \mathrm{Al}_{2} \mathrm{Zn}_{2}$ [30]) and $\tau\left(\mathrm{Mg}_{32}(\mathrm{Al}, \mathrm{Zn})_{49}\right.$ [29]). The authors note that in all binary phases in the system, the solubility of the third element is low, except for the $\sigma$ phase $\left(\mathrm{MgZn}_{2}\right)$. Due to the high solubility of $\mathrm{Al}$ in $\mathrm{MgZn}_{2}$, this phase can also be stated as $\mathrm{Mg}(\mathrm{Al}, \mathrm{Zn})_{2}$. However, the results by Czerwinski [31] indicate that
$\mathrm{Zn}$ atoms can replace some $\mathrm{Al}$ atoms in the $\mathrm{Mg}_{17} \mathrm{Al}_{12}$ phase. It can be then defined as $\operatorname{Mg}_{17}(\mathrm{Al}, \mathrm{Zn})_{12}$.

This work is a part of a larger project on the joining of $\mathrm{Mg}$ and $\mathrm{Al}$ alloys with the $\mathrm{Zn}$ interlayer by compound casting. In our previous paper [23], we focused on the effects of the $\mathrm{Zn}$ interlayer on the microstructure and properties of the joint formed between the AZ31 magnesium alloy and AW-6060 aluminium alloy. The research involved the formation of a $100 \mu \mathrm{m}$ thick $\mathrm{Zn}$ layer on the surface of AW6060 insert by diffusion bonding. The insert was next placed inside a steel mould and heated to $170{ }^{\circ} \mathrm{C}$. Then the AZ31 alloy, heated to $660{ }^{\circ} \mathrm{C}$, was poured into the mould. As a result, a continuous bonding zone with a thickness of $500 \mu \mathrm{m}$ was formed between the alloys. The findings showed that the microstructure of the joint was complex. The layer of a eutectic (a $\mathrm{Mg}_{5} \mathrm{Al}_{2} \mathrm{Zn}_{2}$ phase + a solid solution of $\mathrm{Al}$ and $\mathrm{Zn}$ in $\mathrm{Mg}$ ), a layer of a $\mathrm{Mg}_{32}(\mathrm{Al}, \mathrm{Zn})_{49}$ phase, and a layer of a eutectic $\left(\mathrm{a} \mathrm{Mg}_{32}(\mathrm{Al}, \mathrm{Zn})_{49}\right.$ phase + a solid solution of $\mathrm{Mg}$ and $\mathrm{Zn}$ in $\mathrm{Al}$ ) were detected in the bonding zone.

Furthermore, the bonding zone contained the fine particles of other phases, identified as $\mathrm{Mg}_{17} \mathrm{Al}_{12}$, $\mathrm{Mg}_{2} \mathrm{Si}, \mathrm{Al}_{6}(\mathrm{Fe}, \mathrm{Mn})$, and $\mathrm{Al}_{5} \mathrm{FeSi}$. The analysed joint was characterized by relatively high shear strength. The average shear strength was $42.3 \pm 2.8 \mathrm{MPa}$. The strength of the joint formed without an interlayer was much lower. The highest shear strength values $(8.1 \pm 2.3 \mathrm{MPa})$ were noted for the joint produced with the following process parameters: pouring temperature $660{ }^{\circ} \mathrm{C}$, mould temperature $300^{\circ} \mathrm{C}$. It was shown that the low strength and high brittleness of the analysed joint are correlated with the presence of brittle Mg$\mathrm{Al}$ intermetallic phases in the bonding zone. In this case, the thickness of the bonding zone (approx. 400 $\mu \mathrm{m}$ ) was lower than for the joint fabricated with the $\mathrm{Zn}$ interlayer, despite the use of a higher temperature of the insert.

The present paper deals with the fabrication of an AZ31/AW-6060 joint by compound casting at temperature conditions significantly lower than those applied in our previous work. For this reason, an AW-6060 insert with a Zn surface layer with a steel mould was kept at room temperature. A greater reduction in the temperature of the insert would be inappropriate. Therefore, it was also decided to reduce the temperature of pouring of the AZ31 alloy. This alloy was thus heated to $650{ }^{\circ} \mathrm{C}$ and then poured into the mould. The study focuses on the microstructure analysis and examinations of microhardness and shear strength of the fabricated joint. 


\section{EXPERIMENTAL DETAILS}

AZ31 magnesium alloy and AW-6060 aluminium alloy were used as the materials to be joined. The chemical compositions of the alloys are listed in Table 1.

Table 1. Chemical compositions of AZ31 and AW-6060 alloys [at.\%]

\begin{tabular}{lccccc}
\hline Alloy & Mg & Al & Zn & Si & Mn \\
\hline AZ31 & bal. & 3.07 & 1.05 & - & 0.31 \\
\hline AW-6060 & 0.45 & bal. & - & 0.50 & 0.19 \\
\hline
\end{tabular}

The $30 \mathrm{~mm}$ in diameter and $10 \mathrm{~mm}$ thick specimens were cut from an AW-6060 alloy rod. After cutting, the specimens were subjected to grinding with abrasive papers up to 800 grit and to degreasing with ethanol. The Zn layer was formed on the surface of the AW-6060 alloy by diffusion bonding, by annealing the specimen in contact with a $100 \mu \mathrm{m}$ thick $\mathrm{Zn}$ foil. The annealing was conducted in a vacuum furnace at $375{ }^{\circ} \mathrm{C}$ for 20 minutes. The pressure of $3 \mathrm{MPa}$ was exerted to ensure good contact with the materials. The insert with $\mathrm{Zn}$ surface layer was next placed in a steel mould and kept at room temperature. The mould was then filled with liquid AZ31 alloy, heated to $650{ }^{\circ} \mathrm{C}$ under an inert argon atmosphere.

The specimens for microscopic observations were prepared using standard metallographic procedures. The final polishing was carried out using $0.05 \mu \mathrm{m}$ colloidal silica. No etching was used due to the sufficient revealing of the microstructure of the specimens in contact with water. The microscopic observations were conducted with a Nikon ECLIPSE MA 200 optical microscope (OM) and a JEOL JSM$7100 \mathrm{~F}$ scanning electron microscope equipped with an energy dispersive X-ray spectroscope detector (SEM/ EDS).

The microhardness was tested by Vickers method, using a MATSUZAWA MMT Vickers microhardness tester at a load of $100 \mathrm{~g}$.

The strength of the joints was examined by a simple shear test with a LabTest 5.20SP1 universal testing machine, using the setup described in the previous study [23]. The specimens with dimensions of $7 \mathrm{~mm} \times 7 \mathrm{~mm} \times 20 \mathrm{~mm}$ were cut from the central part of the joints. The shear strength was tested at a displacement of $10 \mathrm{~mm} / \mathrm{min}$.

\section{RESULTS AND DISCUSSION}

Fig. 2a presents the microstructure of the layer fabricated on the surface of AW-6060 alloy by diffusion bonding in contact with the $100 \mu \mathrm{m}$ thick $\mathrm{Zn}$ foil. Microscopic analysis showed that diffusion processes during bonding resulted in forming a continuous joint between the materials used. As a result, $\mathrm{Al}$ and $\mathrm{Zn}$ form a simple phase diagram with no intermetallic phases [28]. The SEM observations at high magnification (Fig. 2b), together with the results of the EDS analysis (e.g., 52.16 at.\% Zn, 47.84 at.\% $\mathrm{Al}$ ), suggested that the interface layer between the $\mathrm{Zn}$ and AW-6060 alloy had a lamellar microstructure and was composed of a solid solution of $\mathrm{Al}$ in $\mathrm{Zn}$ and a solid solution of $\mathrm{Zn}$ in $\mathrm{Al}$.

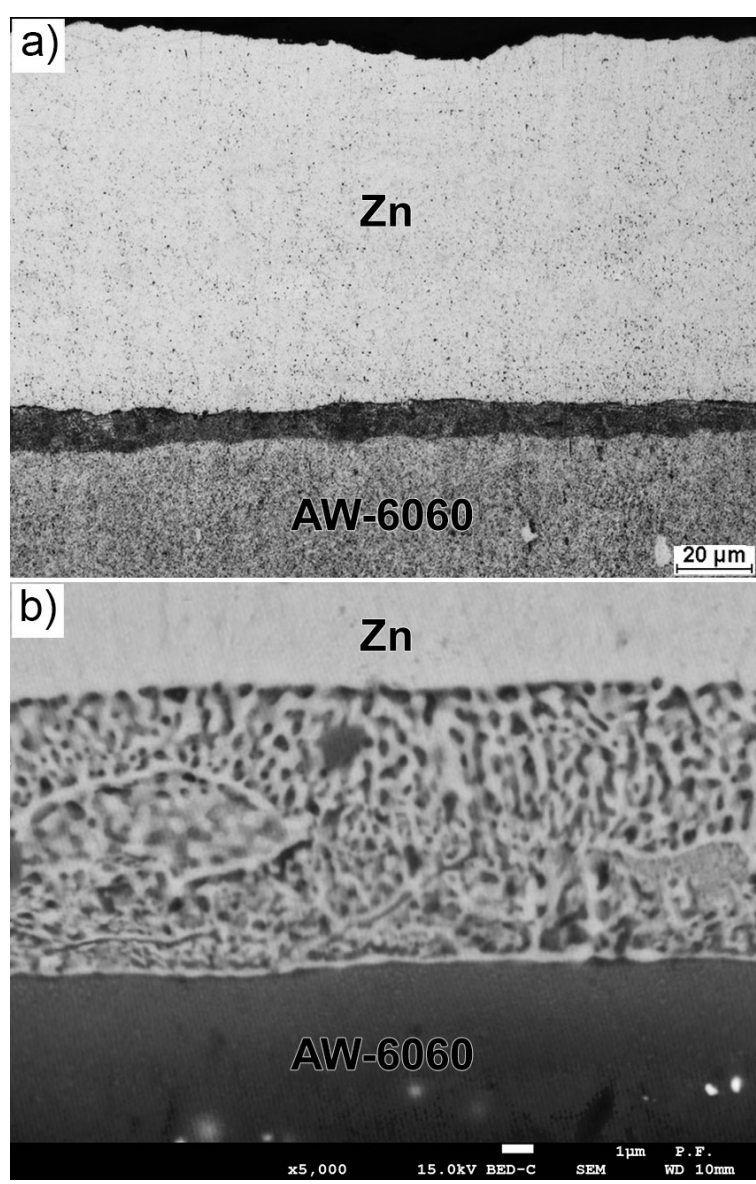

Fig. 2. Microstructure of the layer fabricated on the surface of AW-6060 alloy by diffusion bonding in contact with the Zn foil;

a) OM image, b) high magnification SEM image

Fig. 3 shows the microstructure of the bonding zone formed by pouring the liquid AZ31 alloy at 650 ${ }^{\circ} \mathrm{C}$ onto the solid AW-6060 alloy insert with a Zn surface layer, which was kept at room temperature. The microscopic observations revealed that the joining process resulted in the formation of a continuous bonding zone with a complex structure. The overall thickness of the bonding zone was about $400 \mu \mathrm{m}$. 


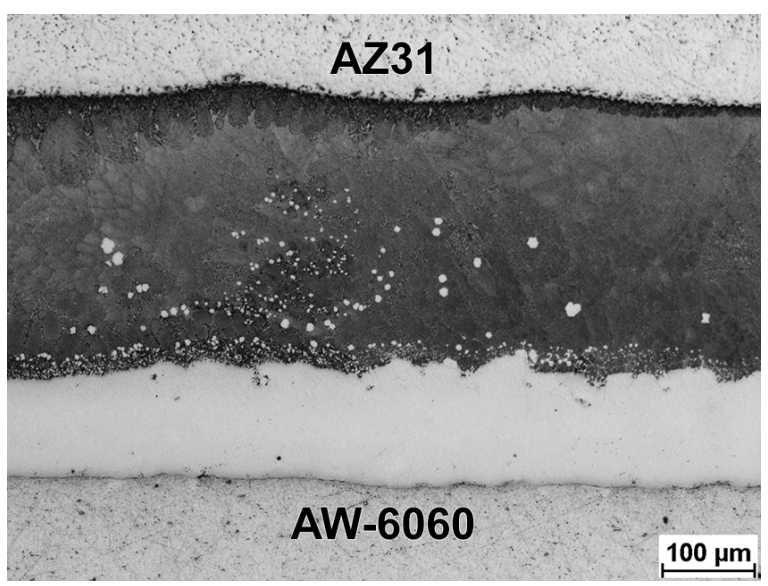

Fig. 3. Microstructure of the bonding zone formed by pouring the liquid AZ31 alloy at $650{ }^{\circ} \mathrm{C}$ onto the solid AW-6060 alloy insert with a Zn surface layer, which was kept at room temperature

Fig. 4 shows the results of an EDS linear analysis throughout the analysed bonding zone. The distribution of elements along the marked line shows a high content of $\mathrm{Zn}$ and $\mathrm{Mg}$, while the concentration of Al was relatively low. The higher content of $\mathrm{Al}$ was recorded only in the transition region, which can be distinguished at the interface between the two characteristic layers of the bonding zone.

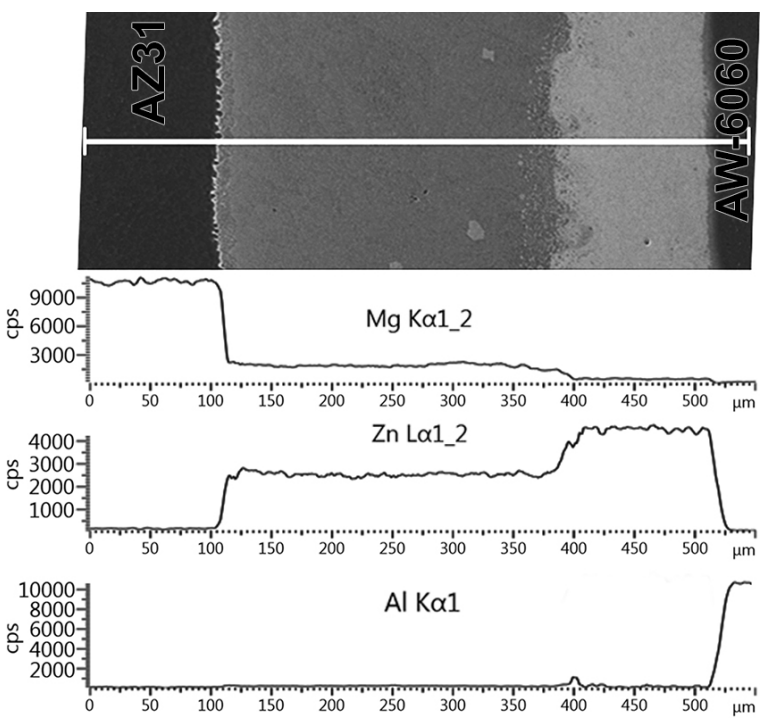

Fig. 4. Results of an EDS linear analysis throughout the bonding zone formed between the AZ31 alloy and AW-6060 alloy with a Zn surface layer

The details of the microstructure of the bonding zone observed in SEM are shown in Fig. 5. The results of EDS point analysis performed in marked points are presented in Table 2. The comparison of the result of analysis carried out in areas marked in Fig. 5a as 1 and 2 showed that the AZ31 alloy in the immediate vicinity of the bonding zone was enriched with $\mathrm{Zn}$. The layer of the bonding zone at the AZ31 alloy side was characterized by a two-phase microstructure. The analysis results carried out in points 3 and 4 suggested that this region was composed of a eutectoid containing a $\mathrm{MgZn}$ intermetallic phase and a solid solution of $\mathrm{Al}$ and $\mathrm{Zn}$ in $\mathrm{Mg}$. The chemical composition of the highly dispersed two-phase area (marked as 5) also indicated a eutectoid (a MgZn phase + a solid solution of $\mathrm{Al}$ and $\mathrm{Zn}$ in $\mathrm{Mg}$ ). In the transition region, which was observed in the central part of the bonding zone, light particles with high content of $\mathrm{Mg}, \mathrm{Zn}$, and $\mathrm{Al}$ were located (point 6 in Fig. 5b). The composition of these particles indicated a $\mathrm{Mg}_{5} \mathrm{Al}_{2} \mathrm{Zn}_{2}$ ternary phase. The analysis carried out in point 7 showed that the chemical composition of the region observed below the eutectoid is also close to a $\mathrm{Mg}_{5} \mathrm{Al}_{2} \mathrm{Zn}_{2}$ phase. In the next layer of the bonding zone (analysis in point 8), a light matrix was observed. Its chemical composition indicated a $\mathrm{Mg}(\mathrm{Al}, \mathrm{Zn})_{2}$ phase. In the structure of this region, fine particles of other phases were also distributed. The results of microscopic observations showed that the particles marked as 9 have a two-phase structure. The small size of these particles made it impossible to perform quantitative analysis in single phases. The result of the analysis in point 9 and the high magnification image presented in Fig. 5c suggests that these particles may be composed of a eutectic containing a $\mathrm{Mg}(\mathrm{Al}, \mathrm{Zn})_{2}$ phase and a solid solution of $\mathrm{Mg}$ and $\mathrm{Zn}$ in $\mathrm{Al}$.

The high content of $\mathrm{Mg}$ and $\mathrm{Si}$ in particles marked as 10 indicated that the darker particles were composed of a $\mathrm{Mg}_{2} \mathrm{Si}$ intermetallic phase, which may originate from the AW-6060 alloy. It can also be formed as a result of diffusion processes between the elements present in the alloys. For example, in [17] and [18], the authors showed that pouring of $\mathrm{Mg}$ alloy onto the $\mathrm{Si}$ containing $\mathrm{Al}$ alloy insert resulted in the formation of fine particles of the $\mathrm{Mg}_{2} \mathrm{Si}$ phase in the bonding zone. The results of the analysis in the area marked as 11 in Fig. 5d showed that the bonding zone on the AW6060 alloy side also consisted of a $\mathrm{Mg}(\mathrm{Al}, \mathrm{Zn})_{2}$ phase with some particles of other phases. Throughout the bonding zone, the light particles containing $\mathrm{Al}, \mathrm{Fe}$ and $\mathrm{Mn}$ or $\mathrm{Al}, \mathrm{Si}$ and $\mathrm{Fe}$ were also found (e.g., 89.67 at.\% $\mathrm{Al}, 7.98$ at.\% $\mathrm{Fe}, 2.35$ at.\% $\mathrm{Mn}$ or 78.26 at.\% $\mathrm{Al}, 13.47$ at.\% Si, 8.27 at.\% Fe, respectively). They probably were particles of multicomponent phases originating from the AW-6060 alloy.

Fig. 6 illustrates the effects of microhardness measurements in AZ31 and AW-6060 alloys and in the bonding zone formed between them. The results 


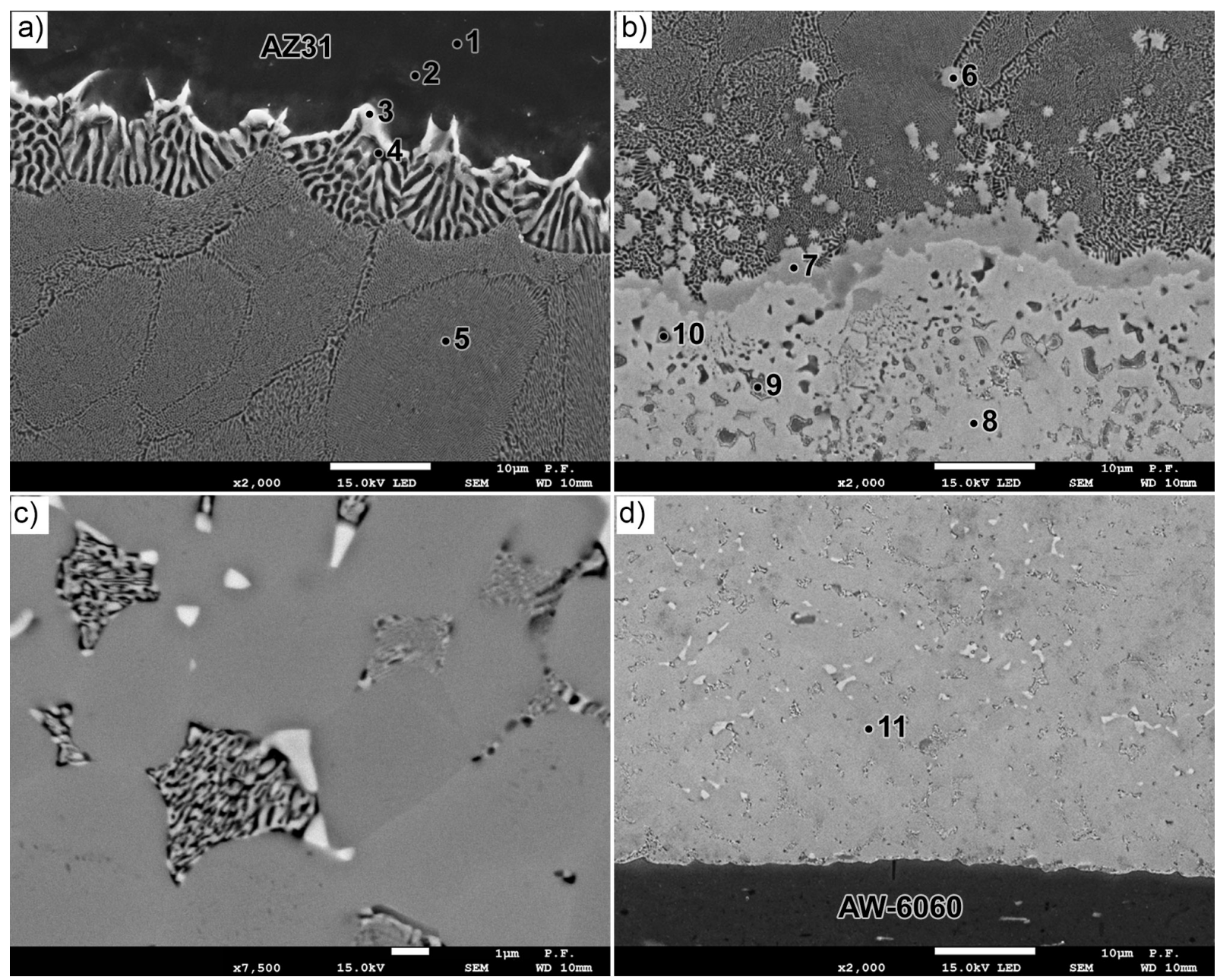

Fig. 5. Details of the microstructure of bonding zone; a) region close to AZ31 alloy, b) the central region, c) high magnification image of the light matrix observed in the central region, d) region close to AW-6060 alloy

showed that a relatively high hardness characterizes the bonding zone. The layer with a two-phase structure (a MgZn phase + a solid solution of $\mathrm{Zn}$ and $\mathrm{Al}$ in $\mathrm{Mg}$ ), which was observed on the $\mathrm{AZ31}$ alloy side, had a microhardness in the range from 214.4 HV0.1 to 225.1 HV0.1. The microphotography presented in Fig. 6b shows that the measurements in this region did not lead to the formation of cracks. In the transition region containing a $\mathrm{Mg}_{5} \mathrm{Al}_{2} \mathrm{Zn}_{2}$ phase (Fig. 6c), a higher microhardness was noted. In this area, the cracks propagating from the corners of Vickers tester impressions were observed. The presence of fine cracks indicates a certain brittleness of this area. The highest microhardness (311.5 HV0.1 to $329.9 \mathrm{HV} 0.1$ ) was reported in the region adjacent to the AW-6060 alloy, which consisted of a $\mathrm{Mg}(\mathrm{Al}, \mathrm{Zn})_{2}$ phase and particles of other phases. Fig. 6 d shows that the microhardness measurements in this region also resulted in the formation of fine cracks indicating the brittleness of the phases.

Table 2. Results of the EDS analysis at points marked in Fig. 5 (at.\%)

\begin{tabular}{ccccc}
\hline Point & $\mathrm{Mg}$ & $\mathrm{Al}$ & $\mathrm{Zn}$ & $\mathrm{Si}$ \\
\hline 1 & 96.40 & 3.03 & 0.57 & - \\
\hline 2 & 93.71 & 4.46 & 1.83 & - \\
\hline 3 & 51.13 & 2.58 & 46.29 & - \\
\hline 4 & 90.99 & 5.81 & 3.20 & - \\
\hline 5 & 68.79 & 5.75 & 25.46 & - \\
\hline 6 & 57.93 & 17.79 & 24.28 & - \\
\hline 7 & 56.14 & 18.42 & 25.44 & - \\
\hline 8 & 32.63 & 2.88 & 64.49 & - \\
\hline 9 & 27.66 & 15.15 & 57.19 & - \\
\hline 10 & 66.14 & 1.14 & 0.98 & 31.74 \\
\hline 11 & 30.98 & 5.59 & 63.43 & - \\
\hline
\end{tabular}



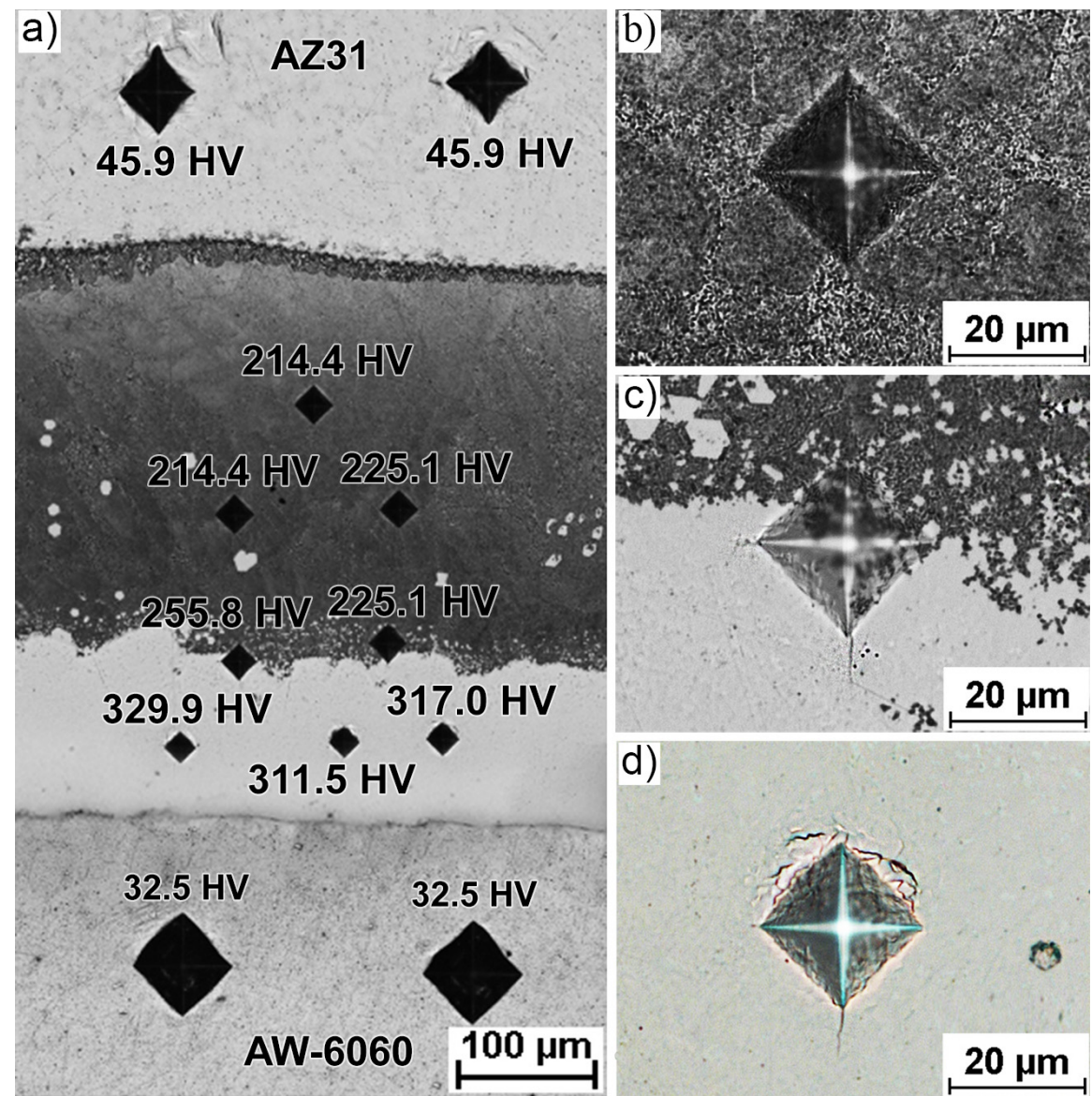

Fig. 6. Results of Vickers microhardness measurements in the bonding zone; a) low magnification image, high magnification of the indentation left in: b) the region close to AZ31 alloy, c) the central region, d) the region close to AW-6060 alloy

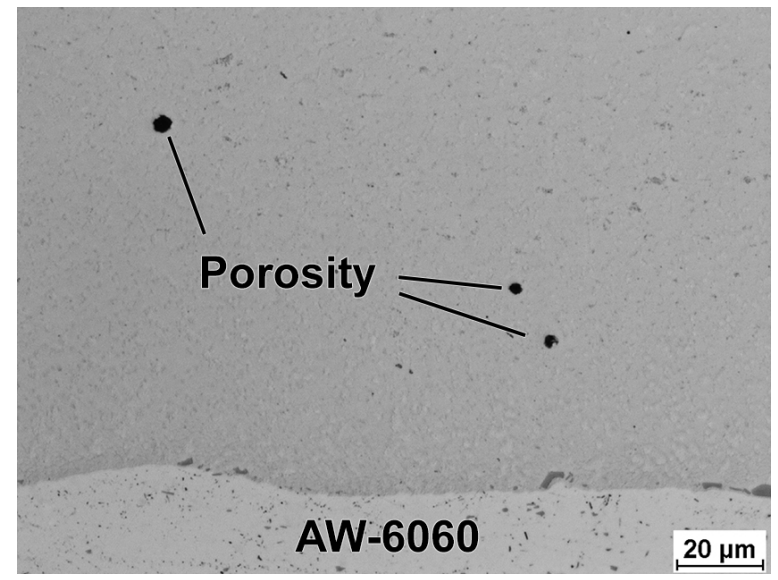

Fig. 7. Details of the microstructure with fine pores locally distributed throughout the bonding zone

From the study it is apparent that as a result of compound casting, a continuous bonding zone with no macroscopic defects was formed between the AZ31 alloy and AW-6060 alloy with a Zn surface layer. The microscopic observations revealed that only fine pores could be found locally in the bonding zone, as shown in Fig. 7.

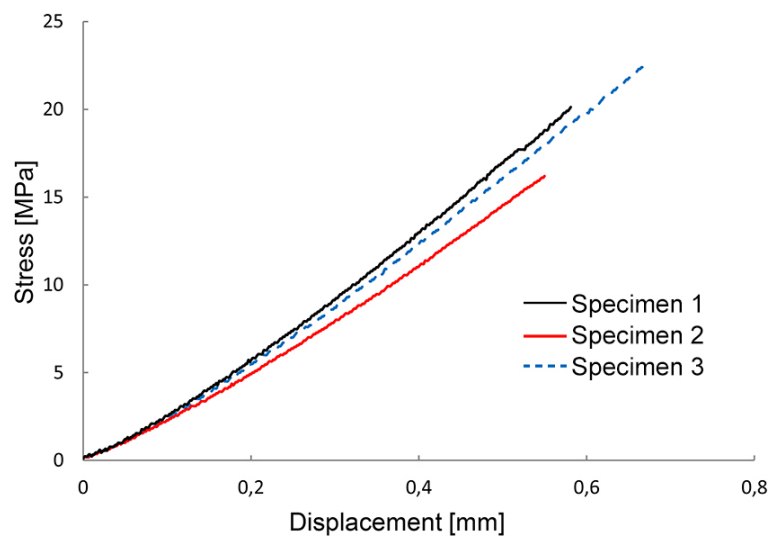

Fig. 8. Results of a simple shear test for the joint produced between the AZ31 alloy and AW-6060 alloy with a Zn surface layer 
Fig. 8 presents the results of a simple shear test performed for the analysed joint. The average shear strength of the tested specimens was $19.6 \pm 2.5 \mathrm{MPa}$. The shape of the stress-displacement curves was typical of brittle materials. No symptoms of plastic deformation were observed.

A comparative analysis of the presented results and the findings from our previous work [23] allowed us to conclude that using a $\mathrm{Zn}$ interlayer may result in substantial changes in the microstructure of the AZ31/AW-6060 joint produced by compound casting at a wide range of process parameters. The use of the $\mathrm{Zn}$ interlayer permitted a significant reduction in the pouring temperature and the temperature of the insert. The presence of $\mathrm{Zn}$ also limited the formation of $\mathrm{Mg}-\mathrm{Al}$ binary phases and led to the creation of phases containing $\mathrm{Zn}$. In addition, the bonding zone in the joint formed with the $\mathrm{Zn}$ interlayer, which was analysed in the present study, was characterized by higher microhardness and better shear strength in comparison to the direct joint. This phenomenon is worth highlighting because the high hardness of such materials typically corresponds with their brittleness and low strength. The results of the present research showed, however, that the Mg-Al intermetallic phases present in the direct joint were characterized by high brittleness, as indicated by significant cracks at the corners of the indentations left by the microhardness tester. Some cracks were also observed for the joint with $\mathrm{Zn}$ interlayer, but the crack dimensions were much smaller despite the higher hardness.

Important insights can be drawn when comparing the joints produced with the $\mathrm{Zn}$ interlayer at different pouring temperatures and $\mathrm{Al}$ alloy insert temperatures. The results show that depending on the temperature conditions, the diffusion of the elements occurs at different rates. The higher temperature led to the greater content of $\mathrm{Al}$ in the bonding zone, while for the joint produced at the lower temperature, the amount of Al remained low. It results in significant differences in the phase composition of the bonding zone. The results of the study are in good agreement with the $\mathrm{Mg}-\mathrm{Al}-\mathrm{Zn}$ phase diagram. The greater content of $\mathrm{Al}$ in the first case resulted in the formation of phases rich in $\mathrm{Mg}, \mathrm{Al}$, and $\mathrm{Zn}$, while the lower content of $\mathrm{Al}$ in the other bonding zone led to the presence of phases rich in $\mathrm{Mg}$ and $\mathrm{Zn}$. Furthermore, the joint made at a higher temperature was characterized by the lowest brittleness and the highest shear strength among all analysed variants.

\section{CONCLUSIONS}

The AZ31/AW-6060 joint was fabricated by the compound casting process. A $100 \mu \mathrm{m}$ Zn layer was produced on the surface of the insert to act as an interlayer. The compound casting involved pouring the liquid AZ31 magnesium alloy at $650{ }^{\circ} \mathrm{C}$ onto a solid AW-6060 aluminium alloy insert with a Zn layer, which was placed in a steel mould and kept at room temperature.

As a result of the experiment, a continuous, a 400 $\mu \mathrm{m}$ thick layer was formed between the alloys. The bonding zone has a complex structure. On the AZ31 alloy side, it was composed of a eutectoid containing a MgZn intermetallic phase and a solid solution of $\mathrm{Al}$ and $\mathrm{Zn}$ in $\mathrm{Mg}$. In the central part of the bonding zone, the particles of a $\mathrm{Mg}_{5} \mathrm{Al}_{2} \mathrm{Zn}_{2}$ ternary intermetallic phase and the thin layer of this phase were observed. The region adjacent to the AW-6060 alloy consisted of a $\operatorname{Mg}(\mathrm{Al}, \mathrm{Zn})_{2}$ phase matrix with fine particles, whose composition indicated that they were the particles of a $\mathrm{Mg}_{2} \mathrm{Si}$ phase, a eutectic $\left(\mathrm{a} \mathrm{Mg}(\mathrm{Al}, \mathrm{Zn})_{2}\right.$ phase, and a solid solution of $\mathrm{Mg}$ and $\mathrm{Zn}$ in $\mathrm{Al}$ ) and multicomponent phases rich in $\mathrm{Al}, \mathrm{Fe}$ and $\mathrm{Mn}$ or $\mathrm{Al}$, $\mathrm{Fe}$ and Si.

The bonding zone was characterized by higher microhardness than that of the joined alloys. The highest microhardness values were observed in the region containing a $\mathrm{Mg}(\mathrm{Al}, \mathrm{Zn})_{2}$ phase and in the layer composed of a $\mathrm{Mg}_{5} \mathrm{Al}_{2} \mathrm{Zn}_{2}$ phase. The microhardness measurements in these areas led to the propagation of small cracks in the vicinity of Vickers tester indenters. Observed cracks indicate a noticeable brittleness of the phases. The average shear strength of the joint was $19.6 \pm 2.5 \mathrm{MPa}$.

\section{REFERENCES}

[1] Kumar, D.S., Phanden, R.K., Thakur, L. (2021). A review on environment friendly and lightweight Magnesium-Based metal matrix composites and alloys. Materials Today: Proceedings, vol. 38, p. 359-364, D0I:10.1016/j.matpr.2020.07.424.

[2] Ahmad, A., Yunxin, W., Hai, G., Lei, L. (2019). Determination of the effect of cold working compression on residual stress reduction in quenched aluminium alloy 2219 block. Strojniški vestnik - Journal of Mechanical Engineering, vol. 65, no. 5, p. 311-318, D0l:10.5545/sv-jme.2018.5938.

[3] Zhang, J., Luo, G., Wang, Y., Xiao, Y., Shen, Q., Zhang, L. (2013). Effect of $\mathrm{Al}$ thin film and $\mathrm{Ni}$ foil interlayer on diffusion bonded Mg-Al dissimilar joints. Journal of Alloys and Compounds, vol. 556, p. 139-142, D0l:10.1016/j.jallcom.2012.12.106.

[4] Patel, V.K., Bhole, S.D., Chen, D.L. (2012). Microstructure and mechanical properties of dissimilar welded Mg-Al joints by ultrasonic spot welding technique. Science and Technology of 
Welding and Joining, vol. 17, no. 3, p. 202-206, D0l:10.1179/ $1362171811 Y .0000000094$.

[5] Hayat, F. (2011). The effects of the welding current on heat input, nugget geometry, and the mechanical and fractural properties of resistance spot welding on $\mathrm{Mg} / \mathrm{Al}$ dissimilar materials. Materials \& Design, vol. 32, no. 4, p. 2476-2484, D0l:10.1016/j.matdes.2010.11.015.

[6] Zettler, R., DaSilva, A.A.M., Rodrigues, S., Blanco, A., DosSantos, J.F. (2006). Dissimilar Al to Mg alloy friction stir welds. Advanced Engineering Materials, vol. 8, no. 5, p. 415421, D0I:10.1002/adem.200600030.

[7] Mróz, S., Mola, R., Szota, P., Stefanik, A. (2020). Microstructure and properties of 1050A/AZ31 bimetallic bars produced by explosive cladding and subsequent groove rolling process. Archives of Civil and Mechanical Engineering, vol. 20, p. 1-15, D0I:10.1007/s43452-020-00084-4.

[8] Liu, F., Zhang, Z., Liu, L. (2012). Microstructure evolution of Al/ Mg butt joints welded by gas tungsten arc with Zn filler metal. Materials Characterization, vol. 69, p. 84-89, D0l:10.1016/j. matchar.2012.04.012.

[9] Zhang, H.T., Song, J.Q. (2011). Microstructural evolution of aluminum/magnesium lap joints welded using MIG process with zinc foil as an interlayer. Materials Letters, vol. 65, no. 2122, p. 3292-3294, D0I:10.1016/j.matlet.2011.05.080.

[10] Scherm, F., Bezold, J., Glatzel, U. (2012). Laser welding of Mg alloy MgAl3Zn1 (AZ31) to Al alloy AlMg3 (AA5754) using ZnAl filler material. Science and Technology of Welding and Joining, vol. 17, no. 5, p. 364-367, Dol:10.1179/13621711 2X13333824902080.

[11] Hajjari, E., Divandari, M., Razavi, S.H., Emami, S.M., Homma, T., Kamado, S. (2011). Dissimilar joining of Al/Mg light metals by compound casting process. Journal of Materials Science, vol. 46, p. 6491-6499, D0l:10.1007/s11431-008-0345-9.

[12] Mola, R., Bucki, T., Dziadoń, A. (2016). Formation of Alalloyed layer on magnesium with use of casting techniques. Archives of Foundry Engineering, vol. 16, no. 1, p. 112-116, D0I:10.1515/afe-2016-0013.

[13] Emami, S.M., Divandari, M., Arabi, H., Hajjari, E. (2013). Effect of melt-to-solid insert volume ratio on $\mathrm{Mg} / \mathrm{Al}$ dissimilar metals bonding. Journal of Materials Engineering and Performance, vol. 22, p. 123-130, D0l:10.1007/s11665-012-0243-y.

[14] Jiang, W., Fan, Z., Li, G., Yang, L., Liu, X. (2016). Effects of melt-to-solid insert volume ratio on the microstructures and mechanical Properties of $\mathrm{Al} / \mathrm{Mg}$ bimetallic castings produced by lost foam casting. Metallurgical and Materials Transactions A, vol. 47, p. 6487-6497, Dol:10.1007/s11661-016-3788-9.

[15] Emami, S.M., Divandari, M., Hajjari, E., Arabi, H. (2013). Comparison between conventional and lost foam compound casting of $\mathrm{Al} / \mathrm{Mg}$ light metals. International Journal of Cast Metals Research, vol. 26, no. 1, p. 43-50, D0l:10.1179/1743 $133612 Y .0000000037$.

[16] Li, G., Yang, W., Jiang, W., Guan, F., Jiang, H., Wu, Y., Fan, Z. (2019). The role of vacuum degree in the bonding of $\mathrm{Al} / \mathrm{Mg}$ bimetal prepared by a compound casting process. Journal of Materials Processing Technology, vol. 265, p. 112-121, DOI:10.1016/j.jmatprotec.2018.10.010.

[17] Li, G., Jiang, W., Yang, W., Jiang, Z., Guan, F., Jiang, H., Fan, Z. (2019). New insights into the characterization and formation of the interface of A356/AZ91D bimetallic composites fabricated by compound casting. Metallurgical and Materials Transactions A, vol. 50, p. 1076-1090, D0l:10.1007/s11661. 018-5022-4.

[18] Jiang, W., Li, G., Fan, Z., Wang, L., Liu, F. (2016). Investigation on the interface characteristics of $\mathrm{Al} / \mathrm{Mg}$ bimetallic castings processed by lost foam casting. Metallurgical and Materials Transactions A, vol. 47, p. 2462-2470, D0l:10.1007/s11661016-3395-9.

[19] Mola, R., Bucki, T., Dziadoń, A. (2017). Effects of the pouring temperature on the formation of the bonding zone between AZ91 and AlSi17 in the compound casting process. IOP Conference Series: Materials Science and Engineering, vol. 179, p. 1-6, D0l:10.1088/1757-899X/179/1/012053.

[20] Mola, R., Bucki, T. (2018). The microstructure and properties of the bimetallic AZ91/AlSi17 joint produced by compound casting. Archives of Foundry Engineering, vol. 18, no. 1, p. 71 76, D0I:10.24425/118814.

[21] Mola, R., Bucki, T. (2020). Characterization of the Bonding zone in AZ91/AlSi12 bimetals fabricated by liquid-solid compound casting using unmodified and thermally modified AISi12 alloy. Strojniški vestnik - Journal of Mechanical Engineering, vol. 66, no. 7-8, p. 439-448, D0l:10.5545/svjme.2020.6703.

[22] Mola, R., Bucki, T. (2018). Characterization of the bonding zone in a ZE41/AISi12 joint fabricated by liquid-solid compound casting. Archives of Foundry Engineering, vol. 18, no. 2, p. 203-208, D0I:10.24425/122529.

[23] Mola, R., Bucki, T., Gwoździk, M. (2019). The effect of a zinc interlayer on the microstructure and mechanical properties of a magnesium alloy (AZ31)-aluminum alloy (6060) joint produced by liquid-solid compound casting. JOM, vol. 71, p. 2078-2086, DOI:10.1007/s11837-019-03405-y.

[24] Li, G., Jiang, W., Guan, F., Zhu, J., Yu, Y., Fan, Z. (2020). Effect of different $\mathrm{Ni}$ interlayers on interfacial microstructure and bonding properties of $\mathrm{Al} / \mathrm{Mg}$ bimetal using a novel compound casting. Journal of Manufacturing Processes, vol. 50, p. 614628, D0l:10.1016/J.jmapro.2020.01.017.

[25] Li, G., Jiang, W., Guan, F., Zhu, J., Zhang, Z., Fan, Z. (2021). Microstructure, mechanical properties and corrosion resistance of A356 aluminum/AZ91D magnesium bimetal prepared by a compound casting combined with a novel Ni-Cu composite interlayer. Journal of Materials Processing Technology, vol. 288, p. 1-12, D0l:10.1016/j. jmatprotec.2020.116874.

[26] Okamoto, H. (1998). Al-Mg (aluminum-magnesium). Journal of Phase Equilibria, vol. 19, p. 598, DOI:10.1361/105497198770341815.

[27] Okamoto, H. (1995). Mg-Zn (magnesium-zinc). Journal of Phase Equilibria, vol. 16, p. 474-475, D0l:10.1007/ BF02645363.

[28] Okamoto, H. (1995). Al-Zn (aluminum-zinc). Journal of Phase Equilibria, vol. 16, p. 281-282, D0l:10.1007/BF02667316.

[29] Liang, H., Chen, S.-L., Chang, Y.A. (1997). A thermodynamic description of the Al-Mg-Zn system. Metallurgical and Materials Transactions A, vol. 28, p. 1725-1734, Dol:10.1007/ s11661-997-0104-8. 
[30] Cheng, K., Sun, J., Xu, H., Wang, J., Zhou, J., Tang, S., Wang, X., Zhang, L., Du, Y. (2021). On the temperature-dependent diffusion growth of $\Phi-M g 5 A I 2 Z n 2$ ternary intermetallic compound in the Mg-Al-Zn system. Journal of Materials Science, vol. 56, p. 3488-3497, D0l:10.1007/s10853-02005439-z.
[31] Czerwinski, F. (2002). The oxidation behaviour of an AZ91D magnesium alloy at high temperatures. Acta Materialia, vol. 50, no. 10, p. 2639-2654, D0l:10.1016/S13596454(02)00094-0. 